УДК 811.111 '42

DOI https://doi.org/10.26661/2414-1135-2021-84-15

\title{
КАРНАВАЛІЗОВАНИЙ АНІМАЦІЙНИЙ ЕКОДИСКУРС: ЕКОЛОГІЯ ЕМОТИВНИХ МОВНИХ ЗАСОБІВ
}

\author{
Івченко Н. С. \\ аспірант кафедри англійської філології \\ Харківський національний університет імені В. Н. Каразіна \\ майдан Свободи 4, Харків, Украӥна \\ orcid.org/0000-0002-6216-2502 \\ natalia.s.ivchenko@karazin.ua
}

\begin{abstract}
Ключові слова:
еколінгвістика, емотивна еколінгвістика, екологічні й неекологічні емотивні мовні засоби, емотіологія, карнавалізований анімаційний екодискурс.
\end{abstract}

Роботу присвячено вивченню взаємодії двох сучасних сфер наукових інтересів лінгвістики - емотіології та еколінгвістики. На їхньому стику сформувалася нова наукова галузь - емотивна еколінгвістика, яка досліджує мову крізь призму екологічної вмотивованості емоцій, що виражені емотивними засобами мови. Емоції є мотиваційною основою вербальної та невербальної поведінки, отже, безпосередньо визначають вибір засобів мовлення, які зі свого боку сприяють екологічному зростанню або знищенню. Уперше доведено, що до емотивних засобів мови належить не лише лексика, але й граматичні, стилістичні й синтаксичні засоби мови, які своєю виразністю сприяють емотивному забарвленню дискурсу.

У дослідженні послідовно розглядаються способи вираження емотивності засобів мови вербальним модусом (номінація (пряма назва емоціі), дескрипція (опис емоційного переживання) та експресія (емотивний вираз)), а також категорії емотивної семантики (афективи (емоційні засоби мови), конотативи (засоби, що мають асоціативне емотивне значення) та потенціативи (неемотивні засоби, що набувають емотивного значення в просторі анімації), репрезентовані в карнавалізованому анімаційному екодискурсі "Zootopia”. Під час передачі змісту емотивної семантики у вищезазначеному типі дискурсу не менш важливим є також і невербальний модус: аудіальний, який передає невербальні особливості мовлення, його гучність, тон, інтонації, звуки анімаційного простору, i візуальний - рухи тіла, жести, міміку, особливості побудови кадру, його яскравість, кут огляду, освітленість тощо. Особливо значущим у випадку саме карнавалізованого анімаційного дискурсу є те, яку саме емотивність транслює невербальний модус, іншими словами, чи він збігається, доповнює, регулює, або, навпаки, протистоїть чи замінює емотивне значення вербального модусу.

У роботі визначено, що позитивна чи негативна забарвленість емотивів не має потенціалу впливати як на екологічність, так і на неекологічність, отже, емотивні засоби мови екологічні, якщо вони спрямовані на успішність комунікації, викладення проблем сьогодення та заохочують до екологічного зростання, і неекологічні, якщо вони орієнтовані на конфлікт і деструкцію екологічного світу. 


\title{
CARNIVALIZED ANIMATED ECODISCOURSE: ECOLOGY OF EMOTIVE LANGUAGE MEANS
}

\author{
Ivchenko N. S. \\ Postgraduate Student at the Department of English Philology \\ V. N. Karazin Kharkiv National University \\ Svobody Sq., 4, Kharkiv, Ukraine \\ orcid.org/0000-0002-6216-2502 \\ natalia.s.ivchenko@karazin.ua
}

Key words: ecolinguistics, emotive ecolinguistics, ecological and non-ecological emotive means of language, emotiology, carnivalized animation ecodiscourse.
The paper focuses on the interaction of two modern areas of linguistics research interests - emotiology and ecolinguistics. At their interface, a new scientific branch was formed - emotive ecolinguistics, which studies language through the prism of ecological motivation of emotions expressed by emotive language means. Emotions are the motivational basis of verbal and non-verbal behaviour, therefore directly determine the choice of language means, which, for their part, contribute to environmental growth or destruction. It is proved for the first time that the emotive means of language include not only vocabulary but also grammatical, stylistic, and syntactic means of language, which by their expressiveness contribute to the emotive colouring of discourse.

The study consistently examines the ways of expressing the emotivity of the language means - verbal mode: nomination (direct naming of emotion), description (means that describe emotional experience) and expression (emotive expression), as well as the categories of emotive semantics: affective (emotional means of language), connotatives (means that have associative emotive meaning) and potentiatives (non-emotional means that acquire emotive meaning in the animation environment) represented in the carnival animated ecodiscourse "Zootopia". Transmitting the content of emotional semantics in the above-mentioned type of discourse, a non-verbal mode is also important: audially it conveys non-verbal features of speech, such as volume, tone, intonation, sounds of animation space, and visual mode - movements, gestures, facial expressions, features of frame construction, its brightness, viewing angle, illumination, etc. In the case of carnivalized animated discourse particularly important is the kind of emotivity transmitted in the non-verbal mode. In other words, whether it coincides, complements, regulates, or, conversely, opposes or replaces the emotive meaning of the verbal mode.

The paper defines that the positive or negative colouring of emotions has potential to affect both environmental friendliness and unfriendliness, therefore, the emotional means of language are ecological if their aim is success of communication or if it highlights the present problems and encourages environmental growth, and non-ecological means if they are focused on conflict and destruction of the ecological world.
Постановка проблеми. Анімація на сучасному етапі розвитку перетворилася на складний, багаторівневий різновид мистецтва, що, комбінуючи вигадку із зображенням стану, феноменів і проблем реального світу, створює складний вигадливий карнавалізований простір анімаційного екодискурсу. За допомогою різних каналів передачі інформації - вербального, візуального й аудіального модусів - карнавалізований анімаційний екодискурс (далі - КАЕД) змушує глядачів разом iз його героями переживати найяскравіший і найрізноманітніший спектр емоцій, як негативних, так і позитивних і навіть змішаних. У зв'язку із чим виникає потреба дослідити екологічність або неекологічність позитивної, негативної та змішаної емотивності, а особливо їхній взаємозв'язок. Іншими словами, вивчити, яким чином емотивні мовні засоби впливають на процес естетико-емоційного пізнання світу й заохочують до пошуку емотивних форм мови, що сприяють екологічному добробуту, а також попереджають про ті форми, що призводять до неекологічних наслідків у КАЕД.

Дослідженням проблем емотивності займалися такі вчені, як Н.О. Мельничук, Н.В. Романова, 
В.О. Самохіна, В.І. Шаховський; різні аспекти еколінгвістики окреслено в працях О.І. Морозової, В.О. Самохіної, А. Fill, Р. Mühlhäusler, A. Stibbe; питання зв'язку емотивності й екології вивчали І.Г. Войтенко, Н.П. Киселюк, В.І. Шаховський. У статті вперше досліджується взаємодія емотивних засобів мови та їхньої екологічності.

Мета й завдання статті - дослідити взаємодію еколінгвістики й емотіології, а також проаналізувати вплив позитивних, негативних і змішаних емотивних засобів мови в єдності з невербальним модусом на предмет екологічності в КАЕД.

Предмет та об'єкт дослідження. Об'єктом зазначеного дослідження постає англомовний карнавалізований анімаційний екодискурс, предметом - аналіз екологічності емотивних засобів мови. Матеріалом дослідження виступає американський комедійний мультфільм "Zootopia".

Виклад основного матеріалу дослідження. Емоції є невід'ємною частиною будь-якої комунікації, особливо екологічної, оскільки саме емоції $є$ мотиваційною основою вербальної та невербальної поведінки. Емоційний інтелект керує вибором мовних і стилістичних засобів залежно від ситуації. Проте різні ситуації викликають різні емоції, часто навіть не лише одну, а цілий комплекс схожих чи протилежних емоцій, що може сприяти як екологічному ставленню до світу чи ситуації, так і неекологічному.

Наше дослідження формується на базі емотивної еколінгвістики, розвитку якої передувало зближення наукових інтересів двох молодих галузей сучасної лінгвістики: емотіології - науки, що вивчає вербалізацію вираження емоцій [1, с. 234], та еколінгвістики - науки, що «досліджує вплив мови на стосунки між людьми, іншими організмами й екологічним середовищем. Іншими словами, еколінгвістика зосереджується на тому, як мова формує, підтримує, впливає або руйнує відносини між людьми, різними формами життя та навколишнім середовищем» [2, с. 104]. У такий спосіб емотивна екологія вивчає не лише естетичність мови, але також спрямованість емотивних засобів мови (позитивних, негативних, амбівалентних) на користь або шкоду соціальному й природному екологічному світу.

Кожне слово або вислів мають певну емоційно-експресивно-оцінну забарвленість, а значить, мають емотивний потенціал. В.I. Шаховський виділяе емотивну лексику, яку поділяє на три групи [1, с. 231]:

1) лексика, що позначає емоції (номінація);

2) лексика, що виражає емоції (експресія);

3) лексика, що описує емоції (дескрипція).

Також він окреслює неемотивну лексику, яка $\epsilon$ «емотивно нейтральною в словниковому значенні» [1, с. 231], але може втілювати емотивний смисл, адже в процесі комунікації набуває певного змісту й емоційного навантаження, оскільки вона пов'язана 3 індивідуальною свідомістю людини $[1$, c. 231]. Такий процес і $є$ проявом семантичної емотивності, у зв'язку із чим автор виявляе три категорії емотивної семантики слова: афективи, конотативи й потенціативи.

На нашу думку, у КАЕД такі три категорії набуває не тільки лексика, але й граматичні, синтаксичні, стилістичні конструкції та інші засоби мови. Таким чином, афективність, власне, і $є$ емотивністю, тобто свідчить про емоційний стан або ставлення; конотативність - емотивність як один iз проявів семантики слова або виразу, додаткове або асоціативне значення слова, виразної граматичної, синтаксичної, стилістичної конструкції, яке в контексті анімації набуло певної позитивної або негативної забарвленості; потенціативність ситуативна емотивність, яка притаманна засобам мови, що за своєю природою не мають емотивної забарвленості, проте можуть набувати емотивності в контексті ситуації та надавати їй певної емоційної забарвленості.

Оскільки КАЕД є складною креативною семіотичною системою, значення в якій формуються за допомогою різних каналів зв'язку - модусів $[3$, c. 40], можна говорити про передачу емотивного змісту не лише засобами вербального, але й за допомогою невербального (аудіального й візуального) модусу, не менш важливого. Словами можна приховати й замаскувати будь-які емоції, а невербальні особливості мовлення (просодію, інтонацію, темп, паузи, висоту тону, гучність мовлення), поведінки (жести, міміку, рухи тіла) - ні, оскільки вони мимовільні за своєю природою та формуються раніше за вербальні, тому здатні демонструвати справжні емоції мовця та прихований зміст ситуації.

На думку В.О. Самохіної, карнавалізований дискурс $є$ єдністю мовної ігрової практики й екстралінгвальних факторів [4, с. 27], для якого характерна інверсія уявлень, перегортання норм, перевертання значення бінарних опозицій [4, с. 27]. А значить, вербальний і невербальний модуси можуть транслювати не тільки однакову емотивність (збігатися, доповнювати, регулювати один одного), але також протилежну або навіть замінювати один одного. Мало того, у випадку саме анімаційного дискурсу на емотивну забарвленість ситуації також здатні впливати невербальні аудіальні засоби, такі як гучність, ритм звуків анімаційного світу й музики, а також ії мажорність або мінорність, і візуальні засоби. До останніх належить використання простору кадру, його освітленість, яскравість і кут огляду глядачем. Проблема взаємозв'язку статусів емотивних засобів мови та їхнього впливу на екологічність чи неекологічність виразів чи ситуацій у цілому досі $\epsilon$ 
маловивченою. Виникає потреба використання негативного емотиву, що створює лише неекологічний тон у просторі карнавалізованого анімаційного екодискурсу, а також позитивного - для створення екологічного тону.

На прикладі гасла міста Зоотопія 3 однойменного мультфільму розглянемо, в який спосіб статус емотивної семантики мовних засобів і спосіб виразу їх емотивності впливає на екологічність або неекологічність. Оскільки один і той самий вислів у різних або навіть схожих ситуаціях може бути позитивно або негативно забарвленим, як наслідок, він може по-різному впливати на екологічність. На думку В.І. Шаховського, емотивність $\epsilon$ «рухливим» явищем та ії можна не просто висловлювати, а також імітувати, стимулювати, приховувати й використовувати 3 метою маніпуляції $[1$, с. 25], що яскраво показано в анімації.

Червоною ниткою весь анімаційний фільм "Zootopia" пронизує гасло однойменного міста (підкреслено):

(1) Young Judy Hopps: Just two-hundred and eleven miles away stands the great city of Zootopia, where our ancestors first joined together in peace and declared that anyone can be anything! [5].

Героєм карнавалізованої ситуації $€$ тварина, яка уособлює себе 3 людиною (ancestors, joined together in peace, declared - слова, які характеризують homo sapiens). Зайчиха викликає емоцію натхнення, яка вербально виражається неемотивною лексикою, що набуває емотивності в ситуації (потенціативи): обставина часу “just” і точний числівник на позначення відстані до омріяного міста "two-hundred and eleven miles away" являють собою експозицію, ніби наближуючи глядача до омріяного міста й створюючи приємну напругу очікування (характерну для емоції натхнення). Далі йде зав'язка, де семантичний повтор "joined together" допомагає глядачу відчути себе частиною подій. Кульмінація - “in реace” - уточнення екологічності цілі події - підводить до головної інформації - розв'язки, що в місті “anyone can be anything”, яка свідчить про можливість усебічної реалізації як мовця, так і його слухачів. Уся фраза побудована за допомогою композиційних елементів, які впливають на емотивне забарвлення, підвищуючи рівень творчого хвилювання. Фраза "anyone can be anything" $\epsilon$ алюзією на натхненну історію здобуття незалежності США або прийняття Загальної декларації прав людини, що проводить асоціації між анімаційним і реальним світом і вказує на екологічність події. Водночас у контексті прикладу вислів обігрується з комічного боку: «будь-хто може бути будь-чим».

Отже, емоція натхнення - це «стан своєрідної напруги й підйому духовних сил людини, що ведуть до виникнення або реалізації задуму й ідей творів науки й мистецтва; творче хвилювання» [6, с. 56]. Емоція також підтримується невербальними засобами, аудіально, голос головної героїні звучить піднесено, вона із захопленням розповідає про Зоотопію, а візуальний модус у широкому кадрі демонструє, як вона радісно розкинула руки, демонструючи гасло (див. рис. 1).

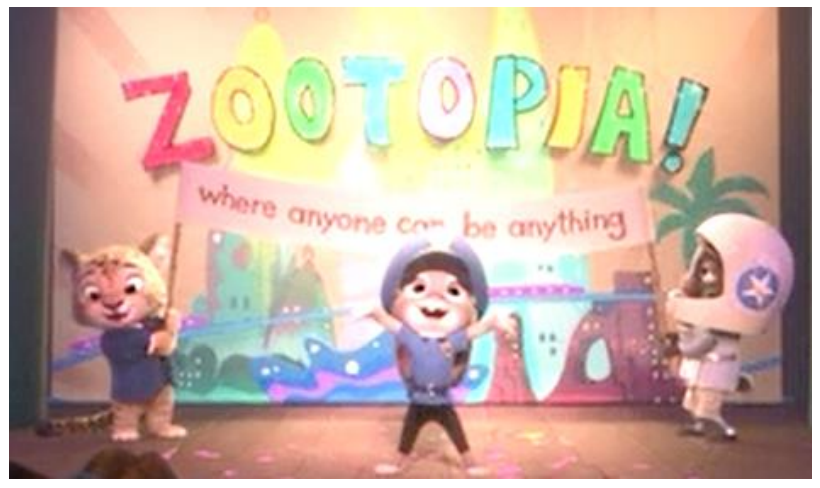

Pис. 1. Zootopia [5], time step: 00:03:05

У наступному прикладі Лис Гідеон, маніпулюючи гаслом анімації (підкреслено), намагається викликати в Джуді емоцію страху:

(2) Young Judy Hopps: You don't scare me, Gideon!

Young Gideon Grey: Scared now?

Travis: Look at her nose twitch! She is scared!

Young Gideon Grey: Cry little baby bunny, cry! Aww, you don't know when to quit, do you? I want you to remember this moment the next time you think you will ever be anything more than just a stupid, carrot-farming dumb bunny! [5].

Наміри Лиса виражені емотивною лексемою, що номінує емоцію "scared" - наляканий чи той, хто боїться, а також лексикою, що описує невербальний типовий прояв емоції "her nose twitch". Як бачимо, сам Лис намагається негативно вплинути на зайчиху, використовуючи конотативну граматичну форму "Cry little baby bunny, cry!" виразне наказове речення із синтаксичним повтором негативного емотивного афективу “cry”, синтаксичним повтором негативних афективів "stupid" і "dumb", а також потенціативів "little baby bunny" й "carrot-farming bunny", які в такому контексті набувають негативного забарвлення та мають на меті принизити зайчиху. Отже, негативна емотивність у наведеному прикладі виражена словами, які називають і висловлюють емоції з метою негативного впливу, що $\epsilon$ неекологічним, оскільки принижують честь і гідність зайчихи.

Наступний раз гасло (підкреслено) з'являється в дуже абсурдній ситуації, коли зайчиха заступилася за двох лисів, а вони намагаються їй віддячити: 
(3) Judy Hopps: And you, little guy, you want to be an elephant when you grow up? You be an elephant. Because this is Zootopia. Anyone can be anything.

Nick Wilde: Ah, boy, I tell him that all the time [5].

У прикладі гасло анімації набуває абсурдної забарвленості, яка проявляється в карнавальному перегортанні онтологічних норм буття (маленький лис хоче стати слоном, коли виросте) і протиставленні емотивності ситуації та емоцій глядача. Зайчиха намагається надихнути маленького Лиса, використовуючи виразний синтаксичний повтор "you want to be an elephant" та "you be an elephant", а також конотатив "little”, який у зазначеному контексті набуває позитивного значення та підтримується візуально (див. рис. 2): маленький лис, одягнений у костюм слона. Отже, гасло знову має надихати, проте вбачаємо, що автори намагалися викликати в глядача емоцію непорозуміння - сумнівів як наслідок того, що він не може зрозуміти, що відбувається [6, с. 221]. Така емоція своєю чергою заохочує до критичного мислення, а візуальний модус демонструє трохи віддалений кадр для того, щоб захопити величезне слоняче морозиво, яке тримає малесенький Лис, одягнений у костюм слона, що підказує: у певному сенсі він уже став слоном. Отже, позитивна емотивність прикладу має екологічний ефект, оскільки вчить глядача критичному й креативному мисленню, карнавально викладаючи проблему самоідентифікації.

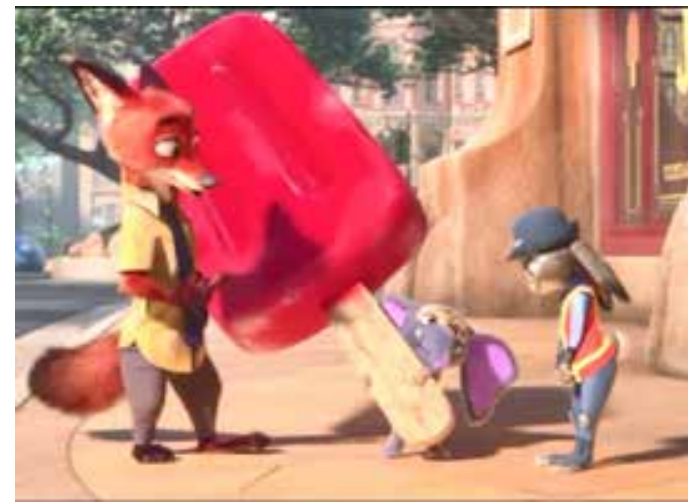

Puc. 2. Zootopia [5], time step: 00:21:35

Коли Зайчиха дізнається, що Лиси ії надурили, гасло міста (підкреслено) викликає емоцію безвиході:

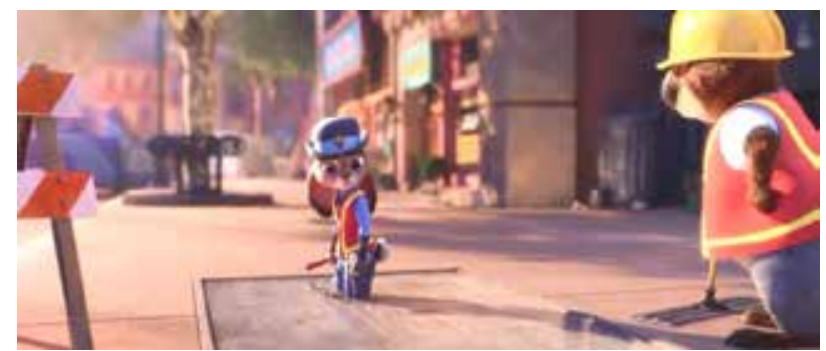

Pис. 3. Zootopia [5], time step: 00:26:03
(4) Judy Hopps: Hey, hey! No one tells me what I can or can't be! Especially not some jerk who never had the guts to try and be anything more than a pawpsicle hustler.

Nick Wilde: All right, look, everyone comes to Zootopia thinking they can be anything they want. Well, you can't. You can only be what you are. Sly fox, dumb bunny.

Judy Hopps: I am not a dumb bunny.

Nick Wilde: Right. And that's not wet cement. You'll never be a real cop. You're a cute meter maid, though. Maybe a supervisor one day. Hang in there! [5].

Емоція безвиході через розуміння неминучості й неможливості виправити неприємне становище чи стан речей [6, с. 37] виражається за допомогою негативної лексики "No one", "can't be", "never", негативних афективів "hustler" - шахрай - i "jerk" - сленгове значення тупа особа; останній аудіально виділяється інтонацією. Важливу роль відіграє граматична конструкція "be what you are", яка набуває негативної потенціативності через концентрацію дієслова «бути», що підсилює пануючу емоцію безвиході, і конотативу "guts", який використовується в негативній критиці. Афективні стереотипні словосполучення "sly fox" та “dumb bunny” підкреслюють неекологічність ситуації, оскільки спрощують та узагальнюють складну дійсність. Позитивний афектив “сиte” також неекологічний у наведеному контексті, тобто свідчить про ігнорування професіоналізму й увагу лише до зовнішності. Нейтральна лексема "wet cement” набула негативної потенціативності, адже була вкладена в карнавалізовану умову: якщо зайчиха “not a dumb bunny”, тоді “that's not wet cement”, що підкреслено візуально (див. рис. 3): віддаляючись, кадр демонструє, що зайчиха застрягла в цементі. А позитивна емотивна конструкція “Hang in there!", яка зазвичай вживається 3 метою підбадьорювання, стала негативною, оскільки використовується як сарказм, a iï пряме значення карнавально підкреслено візуальним модусом (див. рис. 3) - зайчисі доведеться «побути там», оскільки вона застрягла в цементі. Отже, як позитивні, так і негативні емотиви надають гаслу міста негативної забарвленості в такому контексті й підтримують емоцію безвиході, що $\epsilon$ неекологічною, оскільки має руйнівний вплив на стан зайчихи й знеохочує до саморозвитку й сміливих цілей.

(5) Judy Hopps: Oh, thank you so much, I'd appreciate that more than you can imagine, it'd be such an-OHHHH, you are naked!

Yax: Huh? Oh, for sure, we're a naturalist club!

Nick Wilde: Yeah, in Zootopia, anyone can be anything. And these guys? They be naked [5]. 


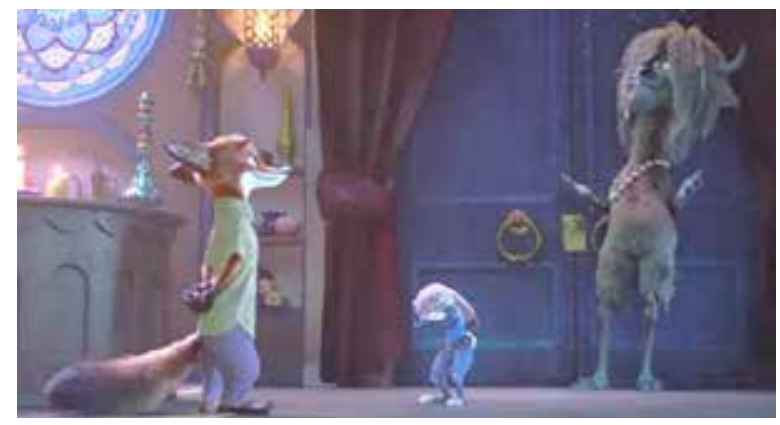

Pис. 4. Zootopia [5], time step: 00:38:17

У прикладі гасло міста з'являється в контексті анімації, який пронизаний незручністю вираження незручності становища, що викликає сором'язливість і дискомфорт, часто проявляється через відведення погляду або затуляння очей [6], що, власне, і демонструє візуальний модус (див. рис. 4): зайчиха затуляє очі лапами. Також емотивність підкреслено аудіально, зайчиха гучно кричить “ОНHНH”, вигук і апосіопеза (головна героїня не закінчила попередню думку) виражають емоцію незручності. Саме гасло в зазначеному контексті використовується іронічно й утворює синтаксичну паралельну конструкцію 3 "they be naked". У такий спосіб нейтральна лексема "naked" набула змішаної емотивності. Використана Зайчихою, вона свідчить про здивування та незручність, а Лисом - іронію, а значить, карнавалізованість. Проте вбачаємо, що емотивність у прикладі екологічна, оскільки він викликає змішані емоції в глядача: з одного боку, незручність, співчуваючи головній героїні, а $з$ іншого, - протиставлення анімаційного й реального світу змушують глядача подивитися на гасло з іншого куту.

Поглянути на гасло через призму удаваного й неудаваного здивування дозволяє й такий приклад:

(6) Judy Hopps: Wait, they're all... sloths? You said this was gonna be quick!

Nick Wilde: [in mock surprise] What, are you saying that because he's a sloth he can't be fast? I thought in Zootopia anyone could be anything. Flash, Flash, hundred-yard dash! Buddy, it's nice to see ya.

Flash Slothmore: Nice to ... see you ... too [5].

Емоція здивування, коли щось здається дивним, неочікуваним і незвичним [6, с. 372], передається за допомогою нейтральної лексеми "sloths", яка виділена інтонаційно - фразовим наголосом і підвищенням гучності мовлення. У такий спосіб вона стає потенціативом. Промовиста граматична конструкція "You said this was gonna be quick!" риторичне непряме питання - підтримує емотивну забарвленість ситуації. А удаване здивування виражене, експресивом "what" і риторичним питанням одразу після нього, підтримує удавану емоцію. Отже, карнавально протиставляючи удаване здивування справжньому, автори створюють екологічний зміст сцени, показуючи, що будь-хто незалежно від походження може бути хорошим працівником, чию роботу треба поважати.

Востанне гасло з'являється наприкінці анімації в промові головної героїні, чиєю метою є надихнути жителів міста:

(7) Judy Hopps: When I was a kid, I thought Zootopia was this perfect place, where everyone got along and anyone could be anything. Turns out, real life is a little bit more complicated than a slogan on a bumper sticker. Real life is messy. We all have limitations, we all make mistakes, which means - hey, glass half full! - we all have a lot in common. And the more we try to understand one another, the more exceptional each of us will be. But we have to try. So, no matter what type of animal you are; from the biggest elephant, to our first fox, I implore you - try. Try to make the world a better place. Look inside yourself and recognize that change starts with you. It starts with me. It starts with all of us [5].

Емотивність прикладу проявляється за допомогою позитивних емотивів, що виражають емоції "perfect" і "better", позитивної афективної конструкції, що $є$ дескрипцією оптимізму "glass half full”, а також позитивного потенціативу “ехсерtional”, яким головна героїня на противагу вживає негативні конотативи “complicated”, “messy”, "limitations”, “mistakes”. У такий спосіб Зайчиха демонструє яскравість і різнобічність життя та за допомогою стилістичного засобу - анафори "change starts with", "it starts with”, яка в контексті набуває позитивного значення, - надихає всіх жителів змінюватися на краще. Карнавальне протиставлення негативних і позитивних конструкцій у наведеному прикладі екологічне, оскільки, реалістично описуючи життя, вони надихають на позитивні зміни. Комізм ситуації посилений тим, що позитивні посили надає тварина (we have to try, make a world a better place, look inside yourself тощо).

Таким чином, одна й та сама фраза може викликати різноманітні емоції залежно від контексту, в якому вживається. А емотивні засоби мови в карнавалізованому контексті анімаційного екодискурсу можуть бути як екологічними, так i неекологічними незалежно від вектора емотивності. Іншими словами, парадоксальність карнавалізованого дискурсу полягає в тому, що як екологічності, так і неекологічності можуть сприяти й позитивні, і негативні емоції.

Висновки й перспективи подальших розробок. Актуальність статті полягає в тому, що емотивні засоби мови вперше досліджуються на матеріалі карнавалізованого анімаційного екодискурсу. Він $є$ складною семіотичною системою, яка 
дозволяє авторам утілювати задум за допомогою емотивних мовних засобів, а також підсилювати їхню значущість і багатогранність за допомогою невербального модусу. До емотивних мовних засобів належать як лексичні, так і граматичні, синтаксичні й стилістичні засоби мови, які, взаємодіючи 3 аудіальним і візуальним модусом в екологічному просторі анімації, можуть набувати негативного, позитивного й амбівалентного значення, створюючи комічні ситуації. Дослідження показало, що один і той самий вислів може набувати різної емотивності (завдяки гумору, сатирі, сарказму й іронії) залежно від емотивів (афективів, конотативів і потенціативів), 3 якими він взаємодіє, і способу їхнього вираження (номінація, дескрипція та експресія), а також сприяти як екологічному розвитку, так і знищенню. Отже, позитивні емотивні засоби мови у взаємодії 3 невербальними засобами можуть підтримувати як екологічне зростання, так і занепад, рівно як i неекологічні.

Перспективно дослідити, які засоби мови набувають емотивності в різних видах дискурсу та яким чином визначені емотивні засоби мови сприяють чи перешкоджають екологічності в інституційних і неінституційних жанрах дискурсу.

\section{ЛІТЕРАТУРА}

1. Шаховский В.И. Диссонанс эко логичности в коммуникативном круге: человек, язык, эмоции : монография). Волгоград : Изд-во ИП Поликарпов И.Л., 2016. 504 с.

2. Alexander R., Stibbe A. From the analysis of ecological discourse to the ecological analysis of discourse. Language sciences. 2014. № 41. P. 104-110.

3. Самохіна В.О., Івченко Н.С. Карнавальне порушення стереотипних норм як шлях до екологізації свідомості (на матеріалі англомовного анімаційного дискурсу "Zootopia”). Вісник ХНУ імені В.Н. Каразіна. Серія: Іноземна філологія. Методика викладання іноземних мов. 2020. № 92. С. 37-44.

4. Самохіна В.О. Карнавалізація у фокусі лінгвокреативної діяльності Homo Artifex. Bicник ХНУ імені В.Н. Каразіна. Серія: Іноземна філологія. Методика викладання іноземних мов. 2019. № 88. С. 26-34.

5. Howard B., Moore R. (Directors) Zootopia [Motion Picture]. United States : Walt Disney Studios, 2016.
6. Летягова Т.В., Романова Н.Н., Филиппов А.В. Тысяча состояний души. Москва : Флинта, 2016. 424 c.

7. Мельничук Н.О. Емотивні прикметники в просторі художніх текстів. Нова філологія. 2021. Вип. 81 Т. 1. С. 225-231.

\section{REFERENCES}

1. Shahovskij, V.I. (2016). Dissonans ekologichnosti $v$ kommunikativnom kruge: chelovek, yazyk, emocii [Dissonance of Environmental Friendliness in the Communicative Circle: Person, Language, Emotions]. Volgograd : IP Polikarpov I.L. [in Russian].

2. Alexander, R., Stibbe, A. (2014). From the analysis of ecological discourse to the ecological analysis of discourse. Language sciences, vol. 41, pp. 104-110.

3. Samokhina V.O., Ivchenko, N.S. (2021). Karnavaljne porushennja stereotypnykh norm jak shljakh do ekologhizaciji svidomosti (na materiali anghlomovnogho animacijnogho dyskursu "Zootopia") [Carnival Violation of Stereotypic Norms as a Way to Ecoconsciousness (based on the English-language animated discourse "Zootopia")]. The Journal of V.N. Karazin Kharkiv National University. Series: Foreign Philology. Methods of Foreign Language Teaching, vol. 92, pp. 37-44. DOI: https://doi.org/10.26565/2227-8877-2020-92-05 [in Ukrainian].

4. Samokhina, V.O. (2019). Karnavalizacija u fokusi linghvokreatyvnoji dijaljnosti Homo Artifex [Carnivalization in the Light of Linguocreative Activity of Homo Artiflex]. The Journal of V.N. Karazin Kharkiv National University. Series: Foreign Philology. Methods of Foreign Language Teaching, vol. 88, pp. 26-34. DOI: https://doi.org/ 10.26565/2227-8877-2018-88-03 [in Ukrainian].

5. Howard, B., Moore, R. (Directors) (2016) Zootopia [Motion Picture]. United States: Walt Disney Studios.

6. Letyagova T.V., Romanova N.N., Filippov A.V. (2016). Tysyacha sostoyanij dushi [Thousand States of Mind]. M: Flinta. [in Russian].

7. Melnychuk, N.O. (2021). Emotyvni prykmetnyky $\mathrm{V}$ prostori khudozhnikh tekstiv [Emotive Adjectives in the Scope of Artistic Texts]. New Philology, vol. 81 № 1, pp. 225-231. DOI: https://doi.org/10.26661/2414-1135-2021-811-34 [in Russian]. 